\title{
Crer que se crê: o Pós-Deus como condição necessária para a fé
}

\author{
Believing that you believe: \\ the After God as a necessary condition for faith
}

Flavio José de Paula

\section{Resumo}

A ideia de Deus, por muito tempo, foi identificada com uma compreensão metafísica da realidade. A entrada do pensamento helênico no cristianismo desistorizou os acontecimentos centrais da revelação e os transformou em categorias ontológicas, fato que chegou ao seu cume no pensamento escolástico, sobretudo nas chamadas provas da existência de Deus, seja com Santo Anselmo, seja com Santo Tomás de Aquino. Tal compreensão do absoluto, no entanto, entrou em crise, principalmente a partir do anúncio de Nietzsche de que Deus está morto e da interpretação heideggeriana deste evento em termos de fim da metafísica. Com o fim da crença nesta estrutura do real, abre-se novamente a possibilidade de se crer, não no sentido forte do termo, isto é, de ter a certeza absoluta de que a totalidade da realidade é algo objetivável, mas ao menos no sentido fraco, do "crer que se crê", enquanto possibilidade de retorno à ideia do Deus bíblico. A partir do fim da Modernidade, entra-se em um tempo que se pode chamar de pós-Deus, pósmetafísico, e, por isso mesmo, em um tempo de superação do discurso hermético, e, consequentemente, de abertura ao Deus revelado em Jesus.

Palavras-chave: Pós-Deus. Pós-modernidade. Fé.

\section{Abstract}

The idea of God, for a long time, was approached with a metaphysical understanding of reality. The entry of Hellenic thought into Christianity dehistoricized the fundamental events of revelation and converted them into 
ontological categories, reaching its peak in Scholastic thought, especially in the so-called proofs of the existence of God, whether with St. Anselm or with St. Thomas Aquinas. This understanding of absolute, however, came into crisis, especially after Nietzsche's announcement that God is dead and Heidegger's interpretation of this event in terms of the end of Metaphysics. From the end of the belief in this structure of the real, the possibility of believing arises again, not in the strong sense of the term: the absolute certainty that the totality of reality is something objectifiable, but, at least, in the weak sense of "believing that you believe" as a possibility of returning to the idea of biblical God. From the end of Modernity, we enter a time that can be called After God, postmetaphysical, and, for that very reason, a time of overcoming hermetic speech, and consequently, opening to the revealed God in Jesus.

Keywords: After God. Postmodernity. Faith.

\section{Introdução}

Falando ao telefone - ainda por cima em um telefone público, exposto, em meio ao barulho do tráfego e das vozes das pessoas - com um velho professor, um homem de muita fé que eu não via há tempos, e que me perguntou se, afinal de contas, eu ainda cria em Deus, respondi: "Bem, creio que creio".

Fazer Teologia, hoje, significa estar em diálogo constante com o mundo e com suas rápidas transformações, mas também com as estruturas de pensamento que se debruçam sobre esses acontecimentos. Um dos pontos centrais, do qual nem a Teologia nem a Filosofia podem se esquivar, é a questão de Deus pensada contemporaneamente, sobretudo a partir de Nietzsche, através da chamada "morte de Deus", e de Heidegger, através do conceito do "fim da metafísica". Levar a sério a questão apresentada, debruçar-se sobre ela e refletir sobre seus impactos é tarefa importantíssima e atual da Teologia.

O presente artigo visa a contribuir nesta discussão, buscando apontar, em um mundo que melhor pode ser apresentado como um "Pós-Deus", qual o espaço para a fé, para a narrativa bíblica, para a vivência que se abre ao divino; em suma, para a experiência cristã. A questão que será abordada, portanto, tratará dos significados da "morte de Deus", de qual Deus Nietzsche constata a

${ }^{1}$ VATTIMO, G., Depois da Cristandade, p. 8. 
morte, e dos impactos do reconhecimento do exílio de Deus na sociedade contemporânea, sobretudo para aqueles que têm fé.

Para argumentar acerca desse assunto, será necessário, antes, apresentar de qual Deus, ou mais precisamente, de qual imagem de Deus, estamos tratando. Por isso, num primeiro momento abordaremos a suplantação do Deus da metafísica ao Deus bíblico, fato esse que, desde as origens do cristianismo, impulsionou um interesse pelo ser, enquanto aspecto ontológico, desprezando o acontecer, enquanto aspecto histórico. Nesse sentido, vale destacar como a questão de Deus era discutida na Idade Média, através de argumentos ontológicos e provas racionais de sua existência. E é exatamente essa imagem de Deus que, de fato, foi por muito tempo identificada com a metafísica, enquanto crença em uma ordem objetiva da realidade.

Com o advento da Modernidade e das novas ciências, tal concepção entrou em colapso, de maneira que Nietzsche pode constatar que "Deus morreu", ou ainda que, em uma perspectiva heideggeriana, não existe mais uma tal ordem objetiva à qual o pensamento humano deva dar o seu consentimento como verdade última. Seja como for, a contemporaneidade não dá mais seu assentimento a verdades que se apresentem como eternas, imutáveis e incorruptíveis, pois, na história, tudo se modifica, tudo se movimenta.

Nesse contexto, e seguindo de perto as reflexões de Vattimo, ${ }^{2}$ nossa hipótese central é de que, com a morte de Deus, seja entendido como o Deus moral, seja compreendido enquanto dissolução da metafísica, ao contrário do que se pensa como sendo o fim de Deus, se nos abre uma outra possibilidade, que outrora foi renegada pela racionalidade extremamente metafísica, a saber, a possibilidade de novamente crer, ou, ao menos, crer que se crê.

\section{A vitória do Deus comum das religiões e do Deus da metafísica sobre o Deus bíblico}

Geralmente, em ambientes cristãos, a imagem que se tem de Deus é, muitas vezes, uma ideia que não advém apenas da bíblia, da reflexão patrística, das fontes primevas, mas sim, principalmente, de outras experiências humanas, como a das religiões, que gera uma ideia comum de Deus, e a das categorias gregas, que produziu uma ideia metafísica do divino. De acordo com Moingt,

\footnotetext{
${ }^{2}$ Gianteresio (Gianni) Vattimo (1936) é um filósofo italiano que se tornou um expoente no tema sobre a pós-modernidade.
} 
A ideia de Deus veiculada inicialmente pelo cristianismo e no decurso dos séculos não foi aquela que hoje podemos extrair do evento revelador de Cristo, mas aquela que ele recebeu ou elaborou constituindo-se e transmitindo-se como religião fundamentada nas Escrituras e em meio à mentalidade pagã e de cultura helenística. [...] O cristianismo rapidamente se apropriou de uma ideia de Deus que pertence ao fundo comum das religiões que ele desenvolveu mais tarde com a ajuda da filosofia para elaborar seu dogma trinitário. Assim se introduziu na religião cristã um conhecimento geral de Deus do qual a modernidade ocidental devia se apoderar antes de rejeitá-lo, o mesmo do qual o cristianismo contemporâneo experimenta a necessidade de se desvencilhar. $^{3}$

Durante muito tempo, falou-se de uma bem-sucedida união entre o cristianismo e o helenismo no pensamento dos Padres da Igreja. Contudo, atualmente, coloca-se em xeque até que ponto uma reelaboração da ideia platônica de Deus conseguiu ser fiel às exigências bíblicas. A objeção que se faz, em síntese, é a seguinte:

A adoção de ideias e sistemas conceituais filosóficos pela teologia cristã representou, particularmente no tocante ao discurso a respeito da essência e das qualidades de Deus, uma adequação adulterante a modos gregos de pensar, sendo, portanto, uma helenização impermissível do cristianismo, a qual, além disso, ainda acabou entrando nos dogmas da Igreja antiga. ${ }^{4}$

Embora comumente se justifique que tal incorporação do pensamento grego tenha sido feita de maneira crítica - e realmente podemos sustentar que os Padres da Igreja não reproduziram a filosofia grega sem a transformar com vistas à revelação -, esse encontro levou a certa generalização da doutrina de Deus no pensamento cristão: a concepção de uma transcendência afastada do mundo venceu a fé no poderio histórico de Deus; os atributos divinos da imutabilidade e da impassividade se impuseram sobre as concepções bíblicas de um Deus que se move em direção ao ser humano e que sofre com ele. Isso

\footnotetext{
${ }^{3}$ MOINGT, J., Deus que vem ao homem, v. I, p. 363-364.

${ }^{4}$ SATTLER, D.; SCHNEIDER, T., Doutrina sobre Deus, p. 82. Contudo, é necessário perceber que "os teólogos da Igreja antiga de forma alguma adotaram, sem correção alguma, a doutrina filosófica de Deus do seu tempo" (SATTLER, D.; SCHNEIDER, T., Doutrina sobre Deus, p. 82).
} 
afetou não apenas a ética cristã, que se tornou temporariamente apática, mas também a Teologia da Trindade e a Teologia da Graça. ${ }^{5}$

Do ponto de vista teológico, nada é mais danoso para a fé do que retratar o fundamento último da esperança cristã a partir de bases alheias, exteriores e independentes. De fato, o fascínio pelo ser metafísico na Teologia foi encobrindo a beleza do acontecer que se revelou em Cristo, e, com isso, não só a Teologia, em geral, e, mais concretamente, a Cristologia, foram prejudicadas, mas também a Igreja, a espiritualidade e a cultura ocidental. ${ }^{6}$ Isto não significa que a fé não deva dialogar com a filosofia - ou ainda, com as ciências, como a sociologia, a economia, a psicologia -, mas significa sobretudo que a Teologia deve entrar em contato com esses setores do conhecimento sem substituir a sua identidade mais profunda. É a partir da identidade cristã que se parte para o diálogo, e não a negando ou a substituindo.

Essa exigência teológica se torna explícita a partir do século XX, com o chamado "retorno às fontes", impulsionado sobretudo pelo Concílio Ecumênico Vaticano II. Essa mudança de direção tem a função de "recuperar tudo o que se perdeu em termos de diálogo e experiências de novas possibilidades humanas por se ter de defender o mundo medieval". ${ }^{7}$ Essa mudança pode ser paradigmaticamente percebida no pensamento rahneriano. A partir do pensamento trinitário de Rahner, a Teologia recuperou alguns elementos que estavam presentes nas origens do cristianismo, mas que se perderam no pensamento rigoroso escolástico, tais como "o enraizamento da reflexão e do discurso teológico na Escritura e o inseparável e indissolúvel entrelaçamento do pensar trinitário com o pensar cristológico, da Trindade com a Cristologia, de Deus com Jesus Cristo e, portanto, com a salvação ou a soteriologia". ${ }^{8}$ De maneira particular podemos apontar o impacto do axioma de Rahner nos estudos teológicos, que fez com que se abandonasse uma postura que partia da filosofia para explicar e estudar o que significa Deus para a vida dos cristãos. De fato, conforme o famoso axioma - "a Trindade econômica é a Trindade imanente, e vice-versa" -, Deus, enquanto Trindade, pode e deve ser encontrado "na concretude de nossa história no espaço e tempo". ${ }^{9}$ Assim, podemos dizer que esse axioma revolucionou os estudos teológicos por apontar uma exigência básica: tudo aquilo que podemos conhecer do mistério de Deus

\footnotetext{
${ }^{5}$ SATTLER, D.; SCHNEIDER, T., Doutrina sobre Deus, p. 82.

${ }^{6}$ CASTILLO, J. M., Jesus, p. 128.

${ }^{7}$ SEGUNDO, J. L., O Dogma que liberta, p. 391.

${ }^{8}$ BINGEMER, M. C. L., Um Deus para ser amado, p. 126.

${ }^{9}$ RAHNER, K., Curso Fundamental da Fé, p. 170.
} 
em si mesmo (Trindade imanente) só pode ser feito com base na revelação, isto é, apoiado na história na qual Deus se relacionou efetivamente e afetivamente com a humanidade (Trindade econômica). ${ }^{10}$ É, portanto, a partir do Deus apresentado pelo Jesus histórico que podemos concretamente falar de Deus, ou seja, aprofundarmo-nos verdadeiramente no "fazer teológico", no sentido mais forte da expressão.

Contudo, sabemos que nem sempre foi assim, pois, por muito tempo se partiu de uma perspectiva filosófica de Deus para, a partir das propriedades divinas devidamente estabelecidas, se falar da revelação. Essa abordagem, que teve início com a influência do helenismo no pensamento cristão primitivo, e que busca a compreensão do ser, negando a importância do acontecer histórico, teve seu cume na chamada Teologia Escolástica.

\subsection{A imagem de Deus na escolástica}

A exigência concreta do axioma rahneriano é que se devia abandonar o esquema teológico medieval, porque este partia principalmente de uma concepção filosófica de Deus. De fato, o estudo da Trindade partia de dois tratados, na prática, independentes: De Deo Uno, que tratava da unidade de Deus, de sua existência, de suas propriedades essenciais; e depois, de certa forma subordinado a esta primeira, o De Deo Trino, que buscava refletir como aquele Deus transcendente, a-histórico, eterno e imutável era, na verdade, um Deus trino. Contudo, a estrutura forte do primeiro tratado sobre o Deus, com suas propriedades substanciais irrevogáveis, sufocava e diminuía a importância da Trindade. Nesse sistema, quem determinava o que era Deus era o pensamento lógico-filosófico e não a imagem apresentada por Jesus de Nazaré. De fato, "a visão teológica mais tradicional, sobretudo a neoescolástica, percebe com extrema dificuldade que a Trindade seja antes de mais nada a manifestação de Deus na história da salvação". ${ }^{11}$

Como exemplo, podemos citar tanto Santo Anselmo de Cantuária quanto Santo Tomás de Aquino como pensadores que se esforçavam sobretudo para provar a existência de Deus partindo da filosofia. Embora ambos vivessem numa sociedade que cria piedosamente e indubitavelmente na existência divina, ambos procuravam demonstrar, através de suas capacidades intelectuais, como se poderia acreditar na existência do Deus uno. A argumentação desses pensadores, mais do que chamar à fé os que duvidavam da existência de Deus - o que não era

${ }^{10}$ RAHNER, K., Curso Fundamental da Fé, p. 65-170.

${ }^{11}$ BINGEMER, M. C. L., Um Deus para ser amado, p. 132. 
o caso da época em que escreviam ${ }^{12}$-, atribuía a Deus propriedades e lhe dava certas características de maneira tão firme e incontestável que gerava, na mentalidade teológica, uma certa imagem de Deus: a do Deus metafísico; e esta, vale dizer, importava mais do que a imagem bíblica.

A célebre sentença de Santo Anselmo baseia-se em uma compreensão lógica-filosófica do conceito de Deus: "Cremos, pois, com firmeza, que tu és um ser do qual não é possível pensar nada maior". ${ }^{13}$ A partir de desdobramentos da própria sentença, Anselmo acredita que podia provar a existência de Deus. ${ }^{14}$ Mas toda a sua argumentação não tem nenhuma relação com a concepção bíblica de Deus. O mesmo se pode dizer de Santo Tomás de Aquino, que, discordando do caminho de Anselmo, ${ }^{15}$ formulou as famosas cinco vias. Entretanto, o autor não buscou outro modo de representar Deus, centrado na revelação; mas, ao contrário, partiu para a prova da existência divina através de um método marcadamente filosófico-aristotélico. Não vem ao caso aprofundar esses argumentos aqui, mas é necessário apontar que essa maneira de se fazer Teologia estava muito distante das questões experienciais e históricas, que são exigidas para se pensar o Deus da Revelação. ${ }^{16}$

12 Notória era a oração de Santo Anselmo antes de apresentar o seu argumento ontológico: "Ó Senhor, tu que nos concedeste a razão em defesa da fé, faze com que eu conheça, até quanto me é possível, que tu existes assim como acreditamos, e que és aquilo que acreditamos" (ANSELMO, Proslógio, 2). Como se vê, não se trata de provar a existência de Deus a quem não tem fé, mas de confirmar que a existência de Deus é conforme a fé, mas provada pela razão, que foi infusa na humanidade para que a ela pudesse chegar por si a Deus mesmo.

${ }^{13}$ ANSELMO, Proslógio, 2.

${ }^{14} \mathrm{Em}$ poucas palavras, seguindo de perto a sua explicação, podemos dizer que a argumentação consiste em afirmar que, primeiro, "ter a ideia de um objeto qualquer na inteligência, e compreender que existe realmente, são coisas distintas"; segundo, a inteligência humana concebe o ser do qual não se pode pensar nada maior, posto que o consegue formular nessas palavras - portanto, este existe em sua inteligência; terceiro, este ser não pode existir só na inteligência, pois se assim o fosse, poderíamos pensar num ser maior do que ele, isto é, um ser que existisse tanto na inteligência quanto na realidade; assim, conclui logicamente que "o ser do qual não se pode pensar nada maior existe, sem dúvida, na inteligência e na realidade” (ANSELMO, Proslógio, 2).

${ }^{15}$ Para Aquino, mesmo considerando que todos possam conceber Deus como algo do qual não se pode pensar nada maior, "não se segue daí que cada um que entenda que aquilo que é significado pelo nome exista na realidade, mas apenas na apreensão do intelecto" (ST I, q. 2. arts. 1-3).

${ }^{16}$ Conforme a Constituição Dogmática Dei Verbum sobre a Revelação Divina, em virtude da revelação, "Deus invisível (Col. 1,15; 1 Tim. 1,17), na riqueza do seu amor fala aos homens como amigos (Ex. 33, 11; Jo. 15,1415) e convive com eles (Bar. 3,38), para os convidar e admitir à comunhão com Ele" (DV 2). Trata-se, portanto, de abordar a questão de Deus, enquanto revelado, a partir de uma experiência íntima, que deve, depois, ser meditada e refletida - mas nunca o contrário. 


\subsection{O Deus que precisava morrer}

O que abordamos em resumo acima, acerca da maneira como a escolástica pensava a questão da existência de Deus, impactou fortemente a concepção mesma de Deus. De fato, tratava-se de uma ideia metafísica de Deus pautada em atributos filosóficos que davam a ideia de um "Deus forte", muito distante daquele apresentado nos relatos evangélicos. Tal concepção, embora trabalhada incansavelmente na Teologia Medieval, teve sua origem na tradição do pensamento helenista. Foi a introdução de tal pensamento na Teologia que fez com que, paulatinamente, a maneira de se pensar e conceber Deus fosse radicalmente invertida. $\mathrm{O}$ impacto na cristologia foi enorme:

A partir do momento em que o pensamento helenista, condicionado mais pela ontologia do "ser" do que pela história do "acontecer", se instalou na forma de interpretar o conteúdo da fé dos principais autores cristãos, iniciou-se um processo de interpretação que progressivamente se foi distanciando dos fatos históricos da vida de Jesus e se vinculando cada vez mais à ontologia do ser do pensamento helenista. ${ }^{17}$

A imagem de Deus, enquanto fundamento último, confunde-se, a partir de então, com a ideia mesma da estrutura metafísica do real; ou seja, postulase Deus a partir de certas premissas que se julgavam, do ponto de vista filosófico, necessárias. É notório, por exemplo, a identificação de Deus com a arché última (princípio, fundamento), a qual, sendo origem de todos os fenômenos, necessariamente teria certas qualidades: "ela [a arché] tinha que ser uma única, pois ao se supor diversos princípios ficaria em aberto a questão da origem da sua diversidade; ela tinha que ser pensada como imutável, ou seja, imóvel e incapaz de sofrimento, isenta de todo dever e perecer". ${ }^{18}$ A sua unicidade restrita, imutabilidade perene e sua impassibilidade diante do sofrimento - justamente as notas que, do ponto de vista filosófico, são as mais essenciais e indispensáveis para se pensar o divino -, em absoluto, não se coadunam com a imagem do Deus de Jesus Cristo.

A imagem de Deus tradicional, danosa à fé bíblica, contudo, entrou em crise. As filosofias e ciências do fim da Modernidade e início da PósModernidade passaram a questionar a metafísica clássica e suas certezas acerca da verdade absoluta. A crença em um Deus com os pressupostos filosóficos foi

${ }^{17}$ CASTILLO, J. M., Jesus, p. 125.

${ }^{18}$ SATTLER, D.; SCHNEIDER, T., Doutrina sobre Deus, p. 81. 
um fator importante no processo de racionalização e disciplina, que favoreceu construir uma visão científica do mundo, abrindo caminho à técnica; mas, paradoxalmente, foi exatamente pelo mesmo motivo que o homem civilizado não sentiu mais a necessidade de crer em Deus, crença esta que passou a ser vista como mentira inútil e obsoleta. ${ }^{19} \mathrm{O}$ processo de racionalização, que antes tentava provar a existência de Deus, passou a tentar provar a sua inexistência, ou, ao menos, a sua irrelevância. Contudo, tanto uma tentativa quanto outra estavam ancoradas na mesma certeza baseada em uma metafísica que, por julgar conter a estrutura do ser, seria absoluta. Deve-se notar, entretanto, que "com a morte de Deus, Nietzsche elimina a possibilidade de qualquer fundamento objetivo e normativo para o mundo e evidencia a precariedade do real". ${ }^{20}$ Sendo assim, se a filosofia não pode mais postular um fundamento definitivo para a realidade, então, também "não existe mais a necessidade de um ateísmo filosófico. Somente uma filosofia 'absoluta' pode se sentir autorizada a negar a experiência religiosa". ${ }^{21}$

Vale destacar ainda que "onde religião e metafísica se condicionam mutuamente, a crítica da razão metafísica [...] deve tornar-se crítica da religião". ${ }^{22}$ Com o advento da Pós-modernidade, e o consequente fim da metafísica clássica, tem-se uma nova abertura à religiosidade. O Deus da metafísica, portanto, devia morrer para que a crença em um Deus vivo, dinâmico, inserido na história e apaixonado pelo mundo pudesse se tornar novamente crível aos olhos do sujeito pós-moderno. Por isso, aquilo que, no fim da Modernidade, à primeira vista, parecia teologicamente negativo - a saber, não sentir mais a necessidade de crer em Deus -, abriu a possibilidade de novamente se crer.

Sob a luz de nossa experiência pós-moderna, isso significa que justamente porque esse Deus-fundamento último, que é a estrutura metafísica do real, não é mais sustentável, torna-se novamente possível uma crença em Deus. Certamente, porém, não no Deus da metafísica e da escolástica medieval que, de qualquer forma, não é o Deus da Bíblia, daquele livro que a própria metafísica moderna, racional e absoluta, aos poucos havia dissolvido e negado. ${ }^{23}$

\footnotetext{
${ }^{19}$ VATTIMO, G., Depois da Cristandade, p. 21.

${ }^{20}$ CARRARA, P. S., Enfraquecimento da ideia de Deus e de homem na pós-modernidade, p. 829.

${ }^{21}$ VATTIMO, G., Depois da Cristandade, p. 12.

${ }^{22}$ METZ, J. B., A fé em história e sociedade, p. 57.

${ }^{23}$ VATTIMO, G., Depois da Cristandade, p. 12.
} 
Se a imagem de Deus, como fundamento metafísico da realidade, entrou em colapso, isso se deve ao fato que ela sofreu um duro "golpe" a partir do século XIX. E este não foi desferido pela Teologia, mas justamente pela Filosofia, sobretudo por autores como Nietzsche e Heidegger.

\section{A morte de Deus}

É conhecidíssimo o trecho do livro de Nietzsche em que o seu principal personagem, Zaratustra, ao descer da montanha onde se encontrava, passa por um velho eremita na floresta. Ao ficar só novamente, "Zaratustra falou assim ao seu próprio coração; 'será possível? Esse velho santo, em sua floresta, ainda não soube que Deus está morto?". ${ }^{24}$ Contudo, trata-se, primariamente, de uma constatação, não da inexistência de Deus em si, mas da percepção de sua inexistência para a sociedade. ${ }^{25}$ De fato, mesmo a partir do pensamento nietzschiano, não se pode afirmar em absoluto a não existência de Deus, pois, segundo Vattimo, o autor mesmo se pergunta, em outros trechos, "se o niilismo não seria compatível com alguma forma de fé no divino, e formula a hipótese da possibilidade de uma religiosidade panteísta, visto que, "no fundo, somente o Deus moral foi superado". ${ }^{26}$

\subsection{A Morte do Deus Moral}

O problema central, em Nietszche, é, portanto, a crítica à moral, estruturada como uma verdade absoluta da qual o ser humano não pode escapar. Nesse sentido, Faus, ao comparar o pensamento de Nietzsche com a crítica de Jesus e de Paulo, constata que "a moralidade, de fato, transforma em fariseus quem a pratica, mas além disso, faz com que todos os que a ditam se convertam em 'aprovados', e em ressentidos, todos aqueles aos quais ela é imposta". ${ }^{27}$ Essa estrutura moral está morta, como se pode perceber, por exemplo, na sociedade europeia, na qual a ausência desse Deus moral, enquanto uma opção da sociedade, "não é um dado prévio ao nosso existir com o qual nos deparamos", mas sobretudo "um exílio de Deus". ${ }^{28}$

\footnotetext{
${ }^{24}$ NIETZSCHE, F., Assim Falou Zaratustra, p. 35.

${ }^{25}$ GONZÁLES FAUS, J. I., Después de Dios, p. 13.

${ }^{26}$ VATTIMO, G., Depois da Cristandade, p. 19.

${ }^{27}$ GONZÁLES FAUS, J. I., Después de Dios, p. 41.

${ }^{28}$ GONZÁlES FAUS, J. I., Después de Dios, p. 13.
} 
Essa estrutura moral fixista, centro da crítica nietzschiana, seja entendida como algo externo, seja percebida como algo interno, é apresentada por Sloterdijk como um problema antropológico. A partir da antropologia filosófica de Helmuth Plessner, o filósofo alemão aponta para uma leitura do ser humano na qual este se vê em uma "posicionalidade excêntrica"; ou seja, na sua vivência histórica particular, o ser humano é "retirado do centro de sua existência e transferido para um ambiente a poder de sua constituição reflexiva". O ser humano, portanto, não se pensa como um ser cujas ações estão voltadas apenas para ele mesmo; mas, ao contrário, por perceber-se "alienado de si mesmo", vêse voltado para algo que lhe é exterior e que lhe julga; embora, ao mesmo tempo, assuma esse papel exterior a si mesmo, com que estivesse ao lado de si mesmo. Assim, "a existência humana assume [...] a forma de uma tarefa que nunca pode ser completamente cumprida: para que a existência seja bemsucedida, ela exige dos indivíduos que eles se moldem à tensão entre tendências excêntricas e concêntricas". ${ }^{29}$

Essa concepção antropológica pode ser melhor compreendida através de uma imagem: a do teatro. De fato, o teorema da "posicionalidade excêntrica", de Plessner, é comparada por Sloterdijk à corrente de pensamento que, desde o Renascimento, compara o ser humano a um ator que sempre está no palco. ${ }^{30} \mathrm{Se}$ assim o é, de fato, o ser humano, percebendo-se sempre visto e julgado por uma plateia que nunca o abandona, para sobreviver, precisa se refugiar atrás de uma máscara. Esta, enquanto símbolo da representação teatral diante do público, cumpre, portanto, um papel moral, pois as ações humanas serão sempre conduzidas não apenas pelas intenções pessoais de cada indivíduo, mas sobretudo pela expectativa do outro que sempre vê. O resultado moral, portanto, é aquilo que chamamos de neutralização de conflitos, uma espécie de "média" entre o desejo pessoal interior e a expectativa exterior. É por isso que uma das causas atuais da crise da fé em Deus, sobretudo no mundo ocidental, é, além da estrutura pluralística da sociedade, a moderna estrutura de nossa personalidade. ${ }^{31}$

Contudo, esse outro - saindo da metáfora teatral, e partindo para uma concepção mais psicológica pautada na filosofia - não é um simples público, mas uma estrutura metafísica sempre presente. De fato, a imagem do divino assume o papel do público absoluto do qual o ser humano não pode escapar.

\footnotetext{
${ }^{29}$ SLOTERDIJK, P., Pós-Deus, p. 34.

${ }^{30}$ SLOTERDIJK, P., Pós-Deus, p. 35. Para o autor, com a sentença de Shakespeare, "all men and women are merely players", iniciou-se a era da antropologia do teatro.

${ }^{31}$ SCHILLEBEECKX, E., História humana, p. 79.
} 
Nas palavras de Sloterdijk: "O Deus que é todo olho, me cerca por fora e radiografa meu interior, segundo o esquema espacial agostiniano de transcendência dupla: [...] ele é mais íntimo do que eu mesmo e mais alto do que minhas concepções mais altas". ${ }^{32}$ Assim, assumindo essa concepção, é uma ilusão desejar estar fora do palco ou longe dos esquemas de representação; é um autoengano negar as máscaras, pois, não existe nada fora do palco. Segundo Duque, a afirmação impactante de um personagem de Nietzsche, "o mais feio de todos os Homens", que dizia que "o Deus que tudo via, mesmo o Homem: esse Deus devia morrer! O Homem não suporta que viva uma tal testemunha!", refere-se à "morte de Deus" na cultura ocidental, uma espécie de "morte cultural de Deus", o fim do grande teatro com todas as consequências para a tradição humanista. ${ }^{33}$

Vale destacar que essa relação entre o que é interior ao ser humano, isto é, ele mesmo, e o que lhe é externo não é uma relação simétrica, mas uma relação desproporcional com o Absoluto. Assim, ocorre o que Sloterdijk chama de "reducionismo", referindo-se à ação humana diante do divino que lhe é infinitamente superior: "a redução parte da evidência solidamente interiorizada segundo a qual o altíssimo insubornável não pode ser levado a mudar de opinião por meio de agrados e sacrifícios. O único método de trazer o Absoluto para o seu lado consistiria em uma entrega total". ${ }^{34}$

No entanto, cabe apontar aqui que, se o Deus moral morreu, conforme constata Nietzsche, então não há mais esse grande outro que sempre vê e julga, e, portanto, as ações humanas não estão mais sob o peso da correspondência a essa estrutura externa. Nesse sentido, as máscaras já não são mais necessárias, pois, se de fato vivemos em uma era do pós-Deus, não há mais necessidade de representação. Em outras palavras, o ser humano pode ser ele mesmo, sem o risco da culpa de ter que se configurar a uma vontade que lhe é externa. ${ }^{35}$

\subsection{A morte do Deus enquanto fim da metafísica}

A morte de Deus não se refere apenas a essa estrutura moral. É notório que "um dos motivos evidentes do enfraquecimento da ideia de Deus na pós-

\footnotetext{
${ }^{32}$ SLOTERDIJK, P., Pós-Deus, p. 44.

${ }^{33}$ DUQUE, J. M., Ambiguidades da secularização entre modernidade e pós-modernidade, p. 21. ${ }^{34}$ SLOTERDIJK, P., Pós-Deus, p. 53.

${ }^{35}$ Conforme enfatizamos, trata-se do Deus moral. De fato, a imagem cristã de Deus nada tem a ver com o outro absoluto que tudo vê e tudo julga, obrigando os seres humanos a se configurar com a vontade externa divina. Ao contrário, a imagem do Deus apresentado na bíblia é relacional, um Deus que se comunica para levar os seres humanos à plena liberdade.
} 
modernidade se explica pelo desprezo da metafísica como instância transcendente portadora de significado para o mundo e para os fatos". ${ }^{36} \mathrm{De}$ fato, foi Heidegger quem traduziu a morte de Deus em Nietzsche nos termos de fim da metafísica. ${ }^{37}$ Conforme dissemos acima acerca da representação de Deus nas discussões da Idade Média, a Teologia Escolástica, de certa forma, identificava Deus com os atributos da verdade última, ou ainda com a arqué, que era, necessariamente, única, imóvel e impassível. ${ }^{38}$ Nesse sentido, a morte de Deus é antes o fim da crença no Deus da metafísica - ou mais especificamente, o fim de uma tradição filosófico-teológica que pensava a estrutura do real a partir de pressupostos da metafísica clássica.

Se partimos da perspectiva heideggeriana acerca do fim da metafísica, obviamente, estamos concordando com o autor acerca do que seja metafísica. Gianni Vattimo, ao defender a tradução da morte de Deus nietzschiana em termos metafísicos feita por Heidegger, tenta sintetizar o pensamento do autor: "O que Heidegger chama de metafísica é, na verdade, a crença em uma ordem objetiva do mundo que o pensamento humano deveria reconhecer para poder adequar tanto suas descrições da realidade quanto suas escolhas morais". Tratase, portanto, da crença absoluta em uma ordem ideal do mundo, em "um reino de essências que vão para além da realidade empírica", ${ }^{39}$ centrada mais no ser, deixando de lado, como superficial, o acontecer. Nesse sentido, a pergunta pelo ente enquanto ente, questão ontológica por excelência, é anterior à pergunta pela realidade. A metafísica, portanto, ao se ocupar com o estudo do ser, "leva diretamente a uma forma de entender as coisas segundo a qual a finalidade da vida consiste em 'fugir do mundo sensivel e terreno para Deus [...] pois o princípio da razão não é a razão, mas algo mais alto"'. ${ }^{40}$

Essa crença na ordem objetiva do mundo, que ao ser humano bastaria reconhecer, sofre uma grande crise, tornando-se, cada vez mais, inaceitável. Em suma, esse pensamento entra em xeque com o chamado existencialismo do século XX, sobretudo pelas reflexões de Heidegger. Se durante muito tempo a metafísica pôde perdurar, é porque ela representava uma perspectiva - embora

\footnotetext{
${ }^{36}$ CARRARA, P. S., Enfraquecimento da ideia de Deus e de homem na pós-modernidade, p. 831. 37 VATTIMO, G., Depois da Cristandade, p. 20. Sabe-se que o conceito "metafísica" é muito amplo e contém muitas definições distintas (embora também possam ser interpretadas como complementares). Contudo, aqui seguimos a perspectiva de Vattimo (p. 19-35). Trata-se, portanto, de abordar mais o conteúdo daquilo objetivado por Heidegger do que discutir o que seja metafísica, propriamente dita, com todas suas implicações.

${ }^{38}$ SATTLER, D.; SCHNEIDER, T., Doutrina sobre Deus, p. 81.

${ }^{39}$ VATTIMO, G., Depois da Cristandade, p. 22.

${ }^{40}$ CASTILLO, J. M., Jesus, p. 128. Grifo do autor.
} 
abordada como única - que permitiu o conhecimento e até a crítica dos limites da realidade. Contudo, com o desenvolvimento das ciências modernas, que transportaram cada vez mais a verdade, outrora parte das ideias platônicas, para a objetividade das proposições da física, "a metafísica passou a desmentir a si própria e se revelou uma crença não mais aceitável". ${ }^{41}$ Embora a organização total da sociedade em si mesma já contestasse a metafísica, a crença em uma ordem objetiva estável se tornou impossível por causa da explosão de imagens do mundo pós-moderno:

A especialização das linguagens científicas, a multiplicidade das culturas (não mais unificadas hierarquicamente pelo mito eurocêntrico), a fragmentação das esferas de existência e do pluralismo babélico da sociedade de fins da modernidade fizeram, de fato, com que se tornasse impensável uma ordem unitária do mundo. Assim, não foram mais dignas de crédito as metanarrativas [...] que pretendiam representar a estrutura objetiva do ser. É em todos estes elementos que consiste o fim da metafísica, que não se resume, portanto, apenas à descoberta, por parte de um filósofo ou de uma escola, de que o ser não é a objetividade na qual a ciência acredita poder reduzi-lo; trata-se de um conjunto de eventos que transformam a nossa existência e sobre as quais a filosofia pós-metafísica se esforça em fornecer uma interpretação [...], e não uma descrição objetiva. ${ }^{42}$

Se a metafísica clássica se interessava pelo ser em detrimento do acontecer, conforme dissemos, buscando a realidade objetiva última, o fim desse sistema de pensamento, ligado por muito tempo à ideia de Deus como eterno, imutável e impassível, pode ser retratado como a "morte de Deus", e, nesse sentido, estamos vivendo em uma época que poderia ser denominada como "pós-Deus". De fato, a metafísica clássica "queria converter o mundo para que participasse da paralisia da onisciência de Deus"; mas, graças à Modernidade, rejeitou-se a ideia de um esvaziamento completo do futuro no passado, excluindo de vez a possibilidade de um Deus onisciente. ${ }^{43}$ Contudo, trata-se do Deus enquanto sistema metafísico, e não do Deus da revelação, pois não há dúvida de que "o pensamento bíblico não é um pensamento metafísico, mas antes de tudo um pensamento histórico". ${ }^{44}$ Assim, compreende-se que "o

\footnotetext{
${ }^{41}$ VATTIMO, G., Depois da Cristandade, p. 23.

42 VATTIMO, G., Depois da Cristandade, p. 23-24.

${ }^{43}$ SLOTERDIJK, P., Pós-Deus, p. 11.

${ }^{44}$ CASTILLO, J. M., Jesus, p. 121.
} 
ato de fé não é da ordem do saber ou da representação" (embora não haja "ato de fé sem representações antropomórficas do mundo"), ${ }^{45}$ mas uma adesão a uma pessoa e a um projeto. Isso significa que, na história da revelação, importa muito mais o acontecer do que o ser; o evento histórico concreto do que as especulações puras destituídas de concretude experiencial. Uma vez feita a distinção entre ser, enquanto ontologia, e acontecer, enquanto história, percebe-se que a metafísica se constituiu pelo interesse do que está fora da história, o que, em termos teológicos, significa uma negação da revelação em si mesma, posto que a orientação fundamental da Teologia "não se centra em saber o que é Deus ou o que é Jesus, mas o que acontece ou o que sucede quando Deus ou quando Jesus se torna presente na vida de uma pessoa, na história de um povo, de uma instituição, de uma cultura". ${ }^{46}$

Em termos concretos, a morte de Deus - entendida como a consciência filosófica de que a metafísica não pode mais postular, com a certeza de outrora, um fundamento definitivo da realidade baseada na essência do ser-implica por um lado, que não existe mais a necessidade de um ateísmo enquanto atitude filosófica, e, por outro, que, justamente por esse Deus-fundamento último não ser mais sustentável, é "novamente possível uma crença em Deus". ${ }^{47}$ Aliás,

É precisamente enquanto herdeira da tradição judaico-cristã, que pensa o real como criação e como história da salvação, que o pensamento pósmoderno se liberta, realmente, da metafísica objetiva, do cientificismo, e passa a ser capaz de corresponder à experiência da pluralidade de culturas e da historicidade contingente do existir. ${ }^{48}$

Portanto, é a própria possibilidade de crer que se torna novamente possível na era do pós-Deus. Nesse sentido, é notória a expressão de Vattimo, "creio que creio", ${ }^{49}$ resultado ambíguo de fé ligado à sua experiência enquanto estudioso de filosofia e intelectual. Na introdução de seu livro "Depois da Cristandade: por um cristianismo não religioso", o filósofo admite que a sua

\footnotetext{
45 THEOBALD, C. A revelação, p. 211.

${ }^{46}$ CASTILLO, J. M., Jesus, p. 121-122.

${ }^{47}$ VATTIMO, G., Depois da Cristandade, p. 12.

${ }^{48}$ VATTIMO, G., Depois da Cristandade, p. 14.

${ }^{49}$ A expressão, embora pareça paradoxal, é explicada por Vattimo nos seguintes termos: "credere tanto pode significar ter fé, convicção, certeza de alguma coisa, quanto opinar ou acreditar em algo com uma certa margem de incerteza. Para dar sentido à expressão ['creio que creio'], eu diria, portanto, que o primeiro credere tem este último significado, ao passo que o segundo deveria manter o primeiro dos significados: ter fé, convicção, certeza”. (VATTIMO, G., Depois da Cristandade, p. 7)
} 
intenção naquela obra era mostrar como o pluralismo pós-moderno permite reencontrar a fé cristã. Se não é mais sustentável a ideia de uma estrutura metafísica do real, que comprovaria a existência do Absoluto, ou, inversamente, uma filosofia que acredite poder demonstrar que Deus não existe, e se "não é da natureza da revelação dar provas de ordem racional", ${ }^{50}$ então "nos vemos novamente livres para escutar as palavras da Escritura". ${ }^{51}$

\section{Conclusão}

O significado mais profundo de Deus, por um longo tempo, foi identificado com o fundamento último buscado pela filosofia. De fato, desde que o cristianismo primitivo entrou em contato com o pensamento helênico, a interpretação feita da realidade se afasta da história, ou melhor, "desistoriza os acontecimentos vividos por Israel e os converte em estranha conversão da interioridade do ser", ou seja, transforma aquilo que foi vivido em um pensamento que "prescinde do dado histórico e se centra na ontologia do ser, interpretado segundo as categorias da ética estoica". ${ }^{52}$ Tal fato, levou a busca por Deus se centrar em argumentos mais filosóficos do que teológicos, como se vê claramente na escolástica, sobretudo nas argumentações que buscavam demonstrar a existência de Deus, tais como o argumento ontológico de Santo Anselmo e as cinco vias de Santo Tomás de Aquino.

Essa imagem de Deus, estritamente ancorada na metafísica, apoiava-se em propriedades da arqué como aquelas imprescindíveis para se pensar a questão de Deus, como a sua unicidade, a sua imutabilidade e a sua impassibilidade, características todas sustentadas pela visão do Deus "forte" onisciente. Tal imagem estruturou também uma consequente interpretação do mundo como uma realidade estável, imutável e eterna.

Com a Modernidade e a Pós-Modernidade e com o advento das ciências especializadas, a crença em tal ordem objetiva do mundo entrou em crise e, sobretudo com a filosofia existencialista do século XX, ela se tornou insustentável. Tal fato já pode ser percebido na constatação de Nietzsche, no século XIX, de que "Deus está morto". Contudo, o que o filósofo aponta é o

\footnotetext{
${ }^{50}$ MOINGT, J., Deus que vem ao homem, v. II, p. 91.

${ }^{51}$ VATTIMO, G., Depois da Cristandade, p. 13.

${ }^{52}$ CASTILlO, J. M., Jesus, p. 124-125. O autor se refere primariamente a Fílon de Alexandria, como exemplo de uma importante corrente judaica que, fortemente influenciada pelo helenismo, passa a interpretar a história de Israel de maneira mais ontológica, prescindindo da história propriamente dita. Contudo, esse autor exerceu enorme influência nas primeiras gerações de autores cristãos, como Clemente de Alexandria, Orígenes e Ambrósio.
} 
fim de uma moral absoluta, capaz de interpretar e determinar todos os atos humanos. Isso é descrito por Sloterdijk como a descoberta de que não existe um "grande outro", que nos vê e nos sonda a todo momento e a quem devemos prestar contas de nossas ações, como se estivéssemos em um palco do qual nunca podemos nos retirar. Com o fim do Deus moral, a liberdade no ser humano é acionada, e ele não se vê mais na necessidade de utilizar máscaras para fugir do confronto entre a sua vontade e a expectativa exterior do que ele deve ser.

Em Heidegger, vemos a tradução da morte de Deus em termos de fim da metafísica. Constata-se, com isso, que não existe mais a crença em uma ordem objetiva última da realidade à qual o ser humano deva reconhecer, seja para se adequar, seja para fazer suas escolhas morais. Desde Nietzsche, "a noção de verdade não mais subsiste e o fundamento não mais funciona, dado que não há fundamento algum para crer no fundamento". ${ }^{53}$ Com isso, a própria possibilidade de crer retorna, pois, se não há fundamento último da verdade, seja para afirmar peremptoriamente a existência de Deus, seja para negá-la definitivamente, o ser humano se torna livre para construir a sua decisão de fé.

Não cremos em um tal Deus no sentido "forte" da palavra, como se a sua realidade tivesse sido demonstrada melhor do que aquela das coisas sensíveis ou dos objetos da física e da matemática. O 'Fides ex audito', um ditado que se origina no Novo Testamento, quer dizer também que no Deus da revelação se crê porque 'se ouviu falar' e, portanto, com toda a margem de incerteza que está ligada a todas as coisas que consideramos verdadeiras porque nos foram ditas por alguém em quem confiamos. ${ }^{54}$

Se, de fato, "o evangelho se viu suplantado pela metafísica", ${ }^{55}$ a era do pós-Deus - esse Deus metafísico e moral - se torna exatamente a época em que o crer desponta como uma possibilidade. Assim compreendendo, fica claro que “a sentença de Nietzsche 'Deus está morto' contém [...] um elemento de ilusão perspectivística: Por mais que ele expresse uma verdade, ela se aplica menos ao fim da história do ser humano com o sobremundo [...] e mais a seu início". ${ }^{56}$ Há que se considerar ainda que, "a originalidade de nossa fé não é crer em Deus como Ser Supremo ou Substância Suprema, ou mesmo como Sujeito

\footnotetext{
${ }^{53}$ VATTIMO, G., O Fim da Modernidade, p. 173.

${ }^{54}$ VATTIMO, G., Depois da Cristandade, p. 15.

${ }^{55}$ CASTILLO, J. M., Jesus, p. 126.

${ }^{56}$ SLOTERDIJK, P., Pós-Deus, p. 37.
} 
Absoluto", ${ }^{57}$ mas entrar em relação com o Deus trinitário. Trata-se, portanto, de um novo período histórico no qual o crer não pode mais ser subjugado pela metafísica, uma época na qual se pode dizer que faz sentido "acreditar que se acredita" em Deus. De fato, podemos afirmar que a "morte de Deus" implicou não só o reconhecimento de uma relação positiva entre Deus e o mundo, mas também se tornou, simbolicamente, condição positiva para a vivência da fé cristã. ${ }^{58}$ Contudo, certamente o Deus que se tornou novamente possível crer não é o da metafísica e da escolástica medieval. Aliás, o retorno ao pensamento hebreu, bíblico, por si só, já é um convite a uma nova "relação ao infinito como infinitamente outro que não pretende submeter nunca a nada, nem a ninguém", "capaz de abrir espaço de transcendência e libertar a metafísica". ${ }^{59}$ Liberta-se, assim, a possibilidade de crer no Deus da história da revelação, justamente porque a concepção moderna de verdade abandonou a posição estática metafísica. Com isso, baseado no novo paradigma pós-moderno de verdade "como uma transmissão de mensagens, como nascimento e morte de paradigmas e interpretações das coisas sob a luz de linguagens históricas herdadas", tornou-se viável novamente que levemos a Bíblia a sério. ${ }^{60}$

\section{Referências bibliográficas}

ANSELMO. Monológio; Proslógio; A Verdade; O Gramático. São Paulo: Abril Cultural, 1979 (Coleção: os Pensadores).

BINGEMER, M. C. L. Crer e dizer Deus Pai, Filho e Espírito Santo (algumas reflexões sobre a teologia trinitária hoje). Atualidade Teológica, v. 5, n. 9, p. 181-203, jul./dez. 2001.

BINGEMER, M. C. L. Um Deus para ser amado: algumas reflexões sobre a doutrina trinitária em Karl Rahner. Perspectiva Teológica, v. 36, n. 98, p. 125141, jan./abr. 2004.

CARRARA, P. S. Enfraquecimento da ideia de Deus e de homem na pósmodernidade. Revista Pistis \& Praxis: Teologia e Pastoral, v. 8, n. 3, p. 817839, set./dez. 2016.

CASTILlO, J. M. Jesus: a humanização de Deus. Petrópolis: Vozes, 2015.

\footnotetext{
${ }^{57}$ BINGEMER, M. C. L., Crer e dizer Deus Pai, Filho e Espírito Santo, p. 189.

${ }^{58}$ DUQUE, J. M., Ambiguidades da secularização entre modernidade e pós-modernidade, p. 24.

59 TEIXEIRA, E., Pós-modernidade e niilismo, p. 215.

${ }^{60}$ VATTIMO, G., Depois da Cristandade, p. 14.
} 
CONCÍLIO VATICANO II. Constituição Dogmática Dei Verbum. In: CONCÍLIO VATICANO II. Compêndio do Vaticano II: constituições, decretos, declarações. 27.ed. Petrópolis: Vozes, 1998. p. 119-139.

DUQUE, J. M. Ambiguidades da secularização entre modernidade e pósmodernidade. Comunicação \& Cultura, n. 11, p. 19-35, jan. 2011.

GONZÁLES FAUS, J. I. Después de Dios. Maliaño (España): Editorial Sal Terrae, 2018.

MOINGT, J. Deus que vem ao homem. Da aparição ao nascimento de Deus. São Paulo: Loyola, 2010. v. II.

MOINGT, J. Deus que vem ao homem. Do luto à revelação de Deus. São Paulo: Loyola, 2010. v. I.

METZ, J. B. A fé em história e sociedade: estudos para uma teologia fundamental prática. São Paulo: Paulinas, 1981.

NIETZSCHE, F. Assim Falou Zaratustra: um livro para todos e para ninguém. Rio de Janeiro: Civilização Brasileira, 2000.

RAHNER, K. Curso Fundamental da Fé: Introdução ao conceito de cristianismo. São Paulo: Paulus, 1989 (Coleção Teologia Sistemática).

SATTLER, D.; SCHNEIDER, T. Doutrina sobre Deus. In: SCHNEIDER, T. (Org). Manual de Dogmática. Petrópolis: Vozes, 2012. p. 53-113. v. I.

SEGUNDO, J. L. O Dogma que Liberta: fé, revelação e magistério dogmático. São Paulo: Paulinas, 2000.

SCHILLEBEECKX, E. História humana: Revelação de Deus. São Paulo: Paulus, 1994.

SLOTERDIJK, P. Pós-Deus. Petrópolis, RJ: Vozes, 2019.

TEIXEIRA, E. Pós-modernidade e niilismo - um diálogo com Gianni Vattimo. Alceu, v.7, n.13, p. 209-224, jul./dez. 2006.

THEOBALD, C. A revelação. São Paulo: Edições Loyola, 2006.

TOMÁS de Aquino. Suma Teológica: O Deus Único: II questão da I parte, artigos 1-3. São Paulo: Loyola, 2009. v. 1.

VATTIMO, G. Depois da Cristandade: por um cristianismo não religioso. Rio de Janeiro: Record, 2004. 
VATTIMO, G. O fim da modernidade: niilismo e hermenêutica na cultura pós-moderna. São Paulo: Martins Fontes, 1996.

Flavio José de Paula Mestrando em Teologia Sistemático-Pastoral pela Pontifícia Universidade Católica do Rio de Janeiro Rio de Janeiro / RJ - Brasil E-mail: flaviodepaulaofs@gmail.com

Recebido em: 28/07/2021 Aprovado em: 14/12/2021 